\title{
Variation Within and Among Vitis spp. for Foliar Resistance to the Powdery Mildew Pathogen Erysiphe necator
}

Lance Cadle-Davidson, United States Department of Agriculture-Agricultural Research Service (USDA-ARS), Grape Genetics Research Unit, Geneva, NY, 14456; David R. Chicoine, New York Chiropractic College, Seneca Falls 13148; and Nancy H. Consolie, USDA-ARS, Grape Genetics Research Unit

\begin{abstract}
Cadle-Davidson, L., Chicoine, D. R., and Consolie, N. H. 2011. Variation within and among Vitis spp. for foliar resistance to the powdery mildew pathogen Erysiphe necator. Plant Dis. 95:202-211.

To complement existing control strategies, grape growers desire cultivars with resistance to powdery mildew caused by Erysiphe necator. Numerous disease resistance screens of diverse Vitis germplasm have been conducted previously to identify powdery mildew resistance but ratings of named cultivars were inconsistent and identities of resistant individuals in wild species were not typically provided. In the current study, controlled inoculations of a single isolate were made onto detached leaves from 1,025 Vitis accessions. The results were compared with natural epidemics in two vineyards: the cold-hardy Vitis spp. repository in Geneva, NY, in 2007-08, and a replicated vineyard of 89 Vitis accessions in Fredonia, NY in 2006-08. Of the genotypes screened using both natural infection and single-isolate inoculation, $33 \%$ were resistant to a single isolate but susceptible to diverse isolates in either or both vineyards, possibly due to race-specific resistance. This was exemplified by selection of E. necator genotypes virulent to

production of the interspecific labrusca hybrids Concord and Niagara. Otherwise, there was good correlation of ratings between the vineyard and single-isolate ratings ( $r=0.55$ to 0.56 ) and between Geneva and Fredonia vineyard ratings $(r=0.75)$. No accession rated in all three screens was immune from infection. Although individual accessions of V. aestivalis, V. palmata, Vitis $\times$ doaniana, and Ampelopsis brevipedunculata were resistant in Geneva and Fredonia, each well-represented species had notable intraspecific variation in resistance. For 129 interspecific hybrids in this and previous studies, ratings infrequently corresponded among previous studies (39\%) and between the current and previous studies (17 to $46 \%$ ). However, three cultivars (Cayuga White, Diana, and Mars) were consistently rated as resistant across four independent studies. The results underscore the importance of uniform testing in multiple environments and the need for strategies for the development of cultivars with durable resistance.
\end{abstract} Vitis labrusca in the Fredonia, NY vineyard, which is surrounded by
The powdery mildew pathogen Erysiphe necator (syn. Uncinula necator) infects green tissues of Vitis spp. everywhere grapevines are grown. Although comprising many of the highest quality grape cultivars, nearly all Vitis vinifera genotypes are susceptible to $E$. necator. As a result, growers rely on fungicides and cultural controls to manage powdery mildew on $V$. vinifera. E. necator is widely accepted to have originated on wild vines in eastern and central North America, and early researchers noted that wild North American Vitis spp. were significantly more resistant to powdery mildew than the European grape $V$. vinifera (12). As a result, grape breeders in the 1800 s attempted to introduce genetic resistance from North American Vitis spp. into French cultivars, resulting in many Vitis interspecific "French-American" hybrids, such as Vignoles and Baco noir.

A major effort to isolate powdery mildew resistance genes and incorporate them into improved cultivars is currently being made by grape breeders and geneticists $(1-5,9,11,13,14,26)$. The most common approach is a pseudo-backcross introgression of resistance from wild accessions into a series of $V$. vinifera recurrent parents known for high fruit quality (16). To this end, an array of genotypes representing dozens of cultivars and Vitis spp. has been

Corresponding author: L. Cadle-Davidson

E-mail: Lance.CadleDavidson@ars.usda.gov

Mention of trade names or commercial products is solely for the purpose of providing specific information and does not imply recommendation or endorsement by the USDA.

Accepted for publication 20 October 2010.

doi:10.1094/PDIS-02-10-0092

This article is in the public domain and not copyrightable. It may be freely reprinted with customary crediting of the source. The American Phytopathological Society, 2011. characterized for resistance to E. necator $(6-8,15,17-19,21,24,25)$. However, most such projects involve uncharacterized populations of the pathogen with isolate presence and frequencies that may be quite different from year to year or from location to location. Further, generalizations are often made about the relative resistance or susceptibility of a species without regard to the variation of resistance within a species.

As a result, relative to more precisely characterized pathosystems such as barley powdery mildew, little is known about E. necator race structure, and only one study has directly demonstrated race specificity using diverse E. necator isolates (10). Nevertheless, anecdotal evidence for race specificity is more widely cited in Vitis spp., as described in a prior review by Roy and Ramming (19), and examples of conflicting ratings abound. For instance, the Vitis interspecific hybrid cv. Vidal blanc is reported to be highly resistant to powdery mildew in Germany (21), and yet is highly susceptible to powdery mildew in New York (27). The inconsistency of relative susceptibility is also temporal. For example, in New York vineyards, Dutchess was reported to be uninfected in 1945 (22) and moderately susceptible in 1987 (27), whereas Missouri Riesling was slightly infected (22) and extremely susceptible (27). Although these observations could be due to differential responses of resistance genes, thus far, only the Run1 and Renl loci of resistance gene analogues from $V$. rotundifolia and $V$. vinifera, respectively, have been directly associated with powdery mildew resistance in Vitis spp. (2,3).

All green tissues of Vitis spp. (berries, pedicels, rachises, shoots, leaves, and buds) can be infected by E. necator. Further, additional Vitaceae species can be infected by some isolates of E. necator (10). Still, resistant individuals have been identified even in the most susceptible Vitis spp. (3). Some of these resistance sources are tissue specific but most confer a similar level of resistance in all green tissues (7). Although the fungus can overwinter as mycelia in dormant buds in warmer climates, only ascospores in cleistothecia survive the winter in colder climates. A bipolar heterothallic 
mating system is required for cleistothecial initiation. The outcrossing necessary for surviving cold winters helps the pathogen overcome disease management strategies, with successful isolates rapidly propagated by polycyclic conidial infections, typically every 10 to 14 days.

Genetic resources for breeding for resistance and other traits are maintained by several international grapevine germplasm repositories and, in the United States, two United States Department of Agriculture-Agricultural Research Service (USDA-ARS) locations maintain a combined total of over 4,100 Vitis accessions (23). This material, freely available worldwide, has been widely used by grape breeders around the world and is maintained for future generations, providing a long-term reference population and genetic resource. Cold-sensitive species are among the major holdings at the National Clonal Germplasm Repository near Davis, CA, whereas the cold-hardy species, breeding lines, and interspecific hybrid cultivars are maintained at the Plant Genetic Resources Unit (PGRU) in Geneva, NY.

The objectives of this study were to characterize the variation in foliar resistance to powdery mildew within and among cold hardy Vitis spp. and to identify candidate accessions for race-specific resistance in the genus Vitis. This is the first comprehensive screen of the PGRU cold-hardy Vitis spp. collection for powdery mildew resistance.

\section{Materials and Methods}

Natural infection in Geneva, NY. Grapevines in the PGRU grape collection are maintained in the field as own-rooted vines at the McCarthy South vineyard, Geneva, NY. Each accession is represented by two adjacent, replicate, own-rooted vines planted with $1.8-\mathrm{m}$ within-row spacing, cane pruned, and trained to the Umbrella Kniffin system using a three-wire trellis. Each accession has a unique plant introduction (PI) number listed in the USDAARS Germplasm Resources Information Network (GRIN) database (23). PI is linked with additional information related to that accession (http://www.ars-grin.gov/npgs/index.html), including species classification, which is presented here without revision. GRIN categorizes interspecific hybrids of V. labrusca and V. vinifera within either V. labrusca or Vitis hybrid.

The vineyard contains two blocks: the I1 block consists of clonally propagated cultivars, breeding lines, and wild species; and the W2 block consists of open-pollinated seedling populations collected from wild vines. Each year, standard production practices were followed for the Finger Lakes region, with vines being sprayed on a chemical rotation at 2-week intervals for the management of powdery mildew, downy mildew, and insects until midAugust, following which time late-season powdery mildew epidemics occurred. Chemicals applied included Rally, Captan, ProPhyt, Rubigan, Penncozeb, and Quintec. Disease ratings were recorded on 15 October 2007 and 24 September 2008, as described below.

Natural infection in Fredonia, NY. Eighty-nine accessions from 14 Vitis spp. and 35 interspecific hybrids were selected for vegetative propagation from the PGRU cold-hardy grape collec- tion. Two- and three-year-old own-rooted grapevines were planted in an experimental vineyard at the Cornell Vineyard Lab in Fredonia, NY, in June 2005 with $1.8-\mathrm{m}$ spacing between vines and in a randomized complete block design with five blocks. Standard production practices for insect, deer, and weed control were followed, but no fungicides were applied in 2006, 2007, and 2008. Disease severity ratings were recorded on 3 October 2006, 8 October 2007, and 22 September 2008. Disease severity was assessed in the vineyard by rating coverage on the adaxial surface of the most heavily infected leaf on a vine. Coverage was rated as the percentage of leaf area with powdery mildew mycelia in $10 \%$ increments and recorded on a 0 -to- 10 scale $(0=$ no visible mycelia and $10=100 \%$ coverage).

Detached-leaf single-isolate inoculations. Detached-leaf inoculations were completed during June to August 2006. A singlespored isolate of E. necator (isolate 10-18) was obtained from a Chardonnay plant in Dresden, NY (10 km south of Geneva, NY) in 2003. A single camel hair affixed to a Pasteur pipette was used to transfer a single conidial chain to a susceptible leaf, viewed under $\times 20$ magnification, and thereafter maintained by bulk transfer. Isolation, amplification, and maintenance of the isolate were done using surface-sterilized, detached leaves of Chardonnay seedlings maintained in $1 \%$ water agar petri dishes. For surface sterilization, leaves were submersed into calcium hypochlorite at $0.88 \mathrm{~g} \mathrm{liter}^{-1}$ for $2 \mathrm{~min}$ with agitation and then washed three times in sterile distilled water for at least $1 \mathrm{~min}$ each. To ensure use of a single isolate for this screen, in April 2006, a single conidial chain of isolate 10-18 was transferred. Fourteen days after transfer, a single conidial chain from the resulting colony was transferred to another sterile, detached leaf. The resulting colony, isolate 10-18-1, was amplified to produce inoculum for the germplasm screen. For inoculum increase, leaves with sporulating colonies were shaken in $40 \mathrm{ml}$ of distilled water with $0.001 \%$ Tween 20 (Sigma-Aldrich, St. Louis) to form a spore suspension. The spore concentration was quantified with a hemacytometer and adjusted to approximately $10^{5}$ conidia/ml, and approximately $0.5 \mathrm{ml}$ of the suspension was applied to susceptible detached leaves using a portable paint sprayer (Preval, Coal City, IL).

Leaves for the screen were collected from the McCarthy South vineyard described above. Twelve days after each biweekly fungicide spray application, replicate leaves were collected for the experiment, with tissue collection initiating a biweekly routine of protocols, until leaves from each accession were collected at least once for screening. In 2006, 1,025 accessions were inoculated using isolate 10-18-1. For each accession, resistance was characterized on the northern vine only of each pair, except when that vine was missing or damaged, in which case the other replicate vine was sampled. Two shoots were arbitrarily selected, and replicates of the fourth-youngest expanded leaf from each shoot were removed and placed into a flexible plastic compact disc (CD) sleeve labeled with the accession number. Each CD sleeve had nine holes punched into it to facilitate wetting during subsequent leaf sterilization and washing. Leaves were collected early in the day before air temperatures reached $29^{\circ} \mathrm{C}$, placed over ice within $15 \mathrm{~min}$

Table 1. Index used in the current study for rating powdery mildew sporulation at $\times 20$ magnification for detached Vitis leaves inoculated with Erysiphe necator isolate $10-18$

\begin{tabular}{ll}
\hline Rating & \multicolumn{1}{c}{ Description } \\
\hline 0 & No conidiophores \\
1 & Conidiophores without conidia \\
2 & Two dozen conidiophores averaging one or fewer conidia each \\
3 & Two dozen conidiophores averaging two to three conidia \\
4 & Two to four dozen conidiophores averaging two to three conidia or two dozen conidiophores averaging four conidia \\
5 & Densely packed conidiophores averaging two conidia or loosely spaced averaging three to four conidia \\
6 & Densely packed conidiophores averaging three to four conidia \\
7 & More than four dozen conidiophores averaging at least four conidia \\
8 & More than four dozen conidiophores averaging at least five conidia \\
9 & Densely packed lawn of conidiophores averaging more than five conidia \\
10 & The entire colony is packed with conidial chains of six or more conidia \\
\hline
\end{tabular}


of collection, and maintained at 4 to $8^{\circ} \mathrm{C}$ until further sample processing within $24 \mathrm{~h}$.

Leaves in CD sleeves were submersed into calcium hypochlorite at $0.88 \mathrm{~g} \mathrm{liter}^{-1}$ for $2 \mathrm{~min}$ with agitation and then washed three times in sterile distilled water for $5 \mathrm{~min}$ each. The leaves were removed from each CD sleeve and plated adaxial side up onto 100by-15-mm petri dishes containing $18 \mathrm{ml}$ of $1 \%$ water agar amended with natamycin (Haorui Pharma-Chem, Edison, NJ) at $0.01 \mathrm{~g} \mathrm{liter}^{-1}$. Each petri dish was prelabeled to track the accession, shoot replicate, and leaf age. Residual water was evaporated by removing the petri dish cover in a sterile laminar flow hood.

After preparation of a complete batch, inoculation was conducted using isolate 10-18-1. Spore suspensions were made as described above, and their concentration was adjusted to $5 \times 10^{4}$ conidia $\mathrm{ml}^{-1}$. Leaves were inoculated using a Preval sprayer and then placed in a $20 \pm 2{ }^{\circ} \mathrm{C}$ growth chamber with a 12 -h photoperiod. Detached leaves were inspected for powdery mildew coverage and sporulation at 21 days post inoculation. Coverage was rated on the 0-to-10 scale described above, and sporulation for the most heavily sporulating colony on each leaf was rated on a 0 -to10 scale described in Table 1.

Data analysis. Analyses of variance (ANOVAs) were completed using SPSS 12 (Chicago). Correlation, descriptive statistics, Tukey's multiple comparisons, and hierarchical clustering analyses were completed using JMP 7.0.1 (SAS Institute, Cary, NC). Predictors included year, location, species, and leaf age with the random variable PI number for each accession and the response variables coverage or sporulation. ANOVA was used to compare "species" as a predictor. For cross-study comparisons, ratings were categorized as resistant, moderate, or susceptible as described in table footnotes. Ratings corresponded when an accession was rated in the same category in two studies. Correspondence was expressed as a percentage of the total comparisons made.

\section{Results}

Natural infection in Geneva, NY. In all, 1,009 Vitis accessions were rated for late-season powdery mildew severity in Geneva, NY. The mean severity was 5.2 in 2007 and 4.3 in 2008, with a range of
0 to 10 in each year. Species varied in their relative susceptibility. No infection was observed on accessions of $V$. romanetii, Vitis $\times$ doaniana, and Ampelopsis brevipedunculata (Table 2). The highest natural severity in Geneva was observed across accessions of $V$. pseudoreticulata, V. vinifera, and V. coignetiae.

Variation was also partitioned within species and between years. The intra- and interspecific variation in powdery mildew resistance for accessions of all well-represented species rated in the Geneva vineyard, using the same $y$-axis scale for each species, is depicted in Figure 1. Within-species variation was evident in all species represented by eight or more accessions (Fig. 1) as well as in V. palmata (five accessions) and Vitis $\times$ champinii (five accessions). Although all species had susceptible accessions, some had a greater proportion of accessions resistant to natural infection (e.g., $V$. amurensis) than did other species (e.g., $V$. acerifolia). To assess year-to-year variability, mean severity ratings for each accession were compared between 2007 and 2008, and 765 of the 926 accessions (83\%) screened in both years had similar ratings (i.e., within $30 \%$ coverage). A majority $(67 \%)$ of this discrepancy was due to higher severity in 2007 , the year with higher mean severity.

Natural infection in Fredonia, NY. In total, 89 Vitis accessions were rated for natural powdery mildew severity in the vineyard. The overall mean severity was 5.2 in 2006, 4.6 in 2007, and 5.0 in 2008 , with a range of 0 to 10 in each year. Species varied in their relative susceptibility (Table 2). Only PI 588271 (V. riparia) was completely free from infection in multiple years. The highest natural severity was observed across accessions of Vitis $\times$ andersonii, $V$. labrusca, and interspecific hybrids.

Variation was also partitioned within species and among years. Within-species variation was evident in $V$. aestivalis, $V$. amurensis, and $V$. rupestris (Table 3). To assess year-to-year variability, mean severity ratings for each accession were compared among the three years at Fredonia, and 305 of the 345 (88\%) comparisons within accession between years had similar ratings (i.e., within $30 \%$ coverage). Surprisingly, most of this between-year disparity (68\%) occurred due to lower disease severity in 2006, even though that was the year with the highest overall disease severity.

Table 2. Variation in Erysiphe necator colony coverage among Vitaceae spp. in natural vineyard infections and single-isolate detached leaf inoculations ${ }^{\mathrm{y}}$

\begin{tabular}{|c|c|c|c|c|c|c|c|c|c|}
\hline \multirow[b]{2}{*}{ Vitaceae spp. $^{\mathrm{z}}$} & \multicolumn{3}{|c|}{ Geneva } & \multicolumn{3}{|c|}{ Fredonia } & \multicolumn{3}{|c|}{ Single-isolate inoculation } \\
\hline & Cvg & Range & No. & Cvg & Range & No. & Cvg & Range & No. \\
\hline Vitis pseudoreticulata & $9.3 \mathrm{abc}$ & $8-10$ & 2 & ND & $\ldots$ & $\ldots$ & 0.0 abcde & $0-0$ & 2 \\
\hline$V$. vinifera & $7.8 \mathrm{a}$ & $0-10$ & 22 & ND & $\ldots$ & $\ldots$ & $6.1 \mathrm{abc}$ & $0-10$ & 22 \\
\hline$V$. coignetiae & $6.3 \mathrm{abcd}$ & $4-8$ & 6 & $4.2 \mathrm{abcd}$ & $0-9$ & 1 & $6.7 \mathrm{a}$ & $0-9$ & 6 \\
\hline Vitis hybrid & $5.5 \mathrm{~b}$ & $0-10$ & 726 & $6.1 \mathrm{a}$ & $0-10$ & 25 & $2.4 \mathrm{bcd}$ & $0-10$ & 738 \\
\hline Vitis $\times$ andersonii & $5.3 \mathrm{abcd}$ & $4-7$ & 1 & $5.8 \mathrm{abcd}$ & $3-8$ & 1 & 0.0 abcde & $0-0$ & 1 \\
\hline Vitis spp. & $5.0 \mathrm{abcd}$ & $0-10$ & 10 & $8.8 \mathrm{a}$ & $1-10$ & 8 & $4.6 \mathrm{ab}$ & $0-10$ & 11 \\
\hline$V$. acerifolia & $4.4 \mathrm{bcd}$ & $0-9$ & 13 & $4.9 \mathrm{abcd}$ & $2-9$ & 5 & 0.7 cde & $0-9$ & 13 \\
\hline Vitis $\times$ novae-angliae & $4.0 \mathrm{abcd}$ & $1-7$ & 1 & $4.2 \mathrm{abcd}$ & $0-9$ & 1 & 0.0 abcde & $0-0$ & 1 \\
\hline V. vulpina & $3.5 \mathrm{bcd}$ & $0-8$ & 13 & $4.0 \mathrm{~d}$ & $3-5$ & 1 & 3.5 bcde & $0-7$ & 13 \\
\hline V. aestivalis & $3.1 \mathrm{bcd}$ & $0-8$ & 8 & $4.0 \mathrm{bcd}$ & $0-10$ & 3 & 0.8 bcde & $0-3$ & 8 \\
\hline$V$. cinerea & $2.7 \mathrm{~cd}$ & $0-8$ & 31 & $2.8 \mathrm{~d}$ & $0-5$ & 4 & $0.1 \mathrm{e}$ & $0-2$ & 32 \\
\hline$V$. riparia & $2.7 \mathrm{~cd}$ & $0-10$ & 70 & $4.1 \mathrm{~d}$ & $0-10$ & 18 & $0.9 \mathrm{de}$ & $0-9$ & 72 \\
\hline V. amurensis & $2.4 \mathrm{~cd}$ & $0-10$ & 15 & $2.8 \mathrm{~cd}$ & $0-9$ & 2 & $0.5 \mathrm{de}$ & $0-6$ & 15 \\
\hline V. labrusca & $2.4 \mathrm{~cd}$ & $0-10$ & 44 & $5.5 \mathrm{abc}$ & $0-10$ & 8 & $3.2 \mathrm{abcd}$ & $0-10$ & 44 \\
\hline$V$. rupestris & $2.2 \mathrm{~cd}$ & $0-9$ & 29 & $3.6 \mathrm{bcd}$ & $0-9$ & 8 & $0.7 \mathrm{de}$ & $0-8$ & 29 \\
\hline Vitis $\times$ champinii & $1.8 \mathrm{bcd}$ & $0-7$ & 5 & ND & $\ldots$ & $\ldots$ & 0.4 bcde & $0-3$ & 5 \\
\hline$V \cdot$ palmata & $1.2 \mathrm{~cd}$ & $0-6$ & 5 & $2.3 \mathrm{~d}$ & $0-8$ & 2 & 1.3 abcde & $0-6$ & 5 \\
\hline V. piasezkii & $0.3 \mathrm{bcd}$ & $0-1$ & 2 & ND & $\ldots$ & $\ldots$ & 4.7 abcde & $0-8$ & 2 \\
\hline Ampelopsis brevipedunculata & $0.0 \mathrm{abcd}$ & $0-0$ & 1 & $1.3 \mathrm{~d}$ & $0-5$ & 1 & 6.5 abcde & $3-10$ & 1 \\
\hline$V$. romanetii & $0.0 \mathrm{~d}$ & $0-0$ & 4 & ND & $\ldots$ & $\ldots$ & 0.0 bcde & $0-0$ & 4 \\
\hline Vitis $\times$ doaniana & $0.0 \mathrm{abcd}$ & $0-0$ & 1 & $1.1 \mathrm{~d}$ & $0-7$ & 1 & 0.0 abcde & $0-0$ & 1 \\
\hline Mean & 4.9 & $\ldots$ & $\ldots$ & 4.8 & $\ldots$ & $\ldots$ & 2.3 & $\ldots$ & $\ldots$ \\
\hline Sum & $\ldots$ & $\ldots$ & 1,009 & $\ldots$ & $\ldots$ & 89 & $\ldots$ & $\ldots$ & 1,025 \\
\hline
\end{tabular}

${ }^{\text {y }} \mathrm{Cvg}=$ mean coverage $(0=0 \%, 1=1$ to $10 \% \ldots 10=100 \%)$, calculated by averaging all rated leaves for that category, based on natural infection of the most heavily infected leaf per vine in Geneva (2007-08) and Fredonia (2006-08) or on single-isolate inoculations with isolate 10-18-1 on detached leaves in 2006. Groupings with the same letter were not significantly different in Tukey's multiple comparisons analysis at $\alpha=0.05$. Range $=$ range of mean rating of each accession in a given species; No. = number of accessions rated; ND = no data, due to the vine not being planted.

${ }^{\mathrm{z}}$ Species listed for each accession, provided in the Germplasm Resources Information Network database (http://www.ars-grin.gov/npgs/index.html), sorted by Geneva coverage. Vitis interspecific hybrids are listed as Vitis hybrid. Unclassified species are listed as Vitis spp. 
Detached-leaf single-isolate inoculations. The species with the highest mean severity across all tested accessions were $V$. coignetiae, A. brevipedunculata, and $V$. vinifera for coverage on the fourth leaf (Table 2). No infection was observed on accessions of five underrepresented species, and accessions of $V$. cinerea were typically resistant (Table 2). Within-species variation was pronounced in all species represented by eight or more accessions (Fig. 1) as well as in V. palmata (five accessions).
Correlation of natural and single-isolate powdery mildew severity. In all, 89 genotypes were tested for powdery mildew severity using both natural infection at two locations in New York State and single-isolate inoculation of detached leaves (Table 3). Thirty-two (33\%) were resistant to single-isolate inoculation but at least moderately susceptible (mean vineyard severity $\geq 5$ ) to naturally occurring isolates in at least one vineyard (Table 3 ). Of these 32 accessions, $5(16 \%)$ plus 2 additional $V$. labrusca accessions had significantly less powdery mildew coverage in

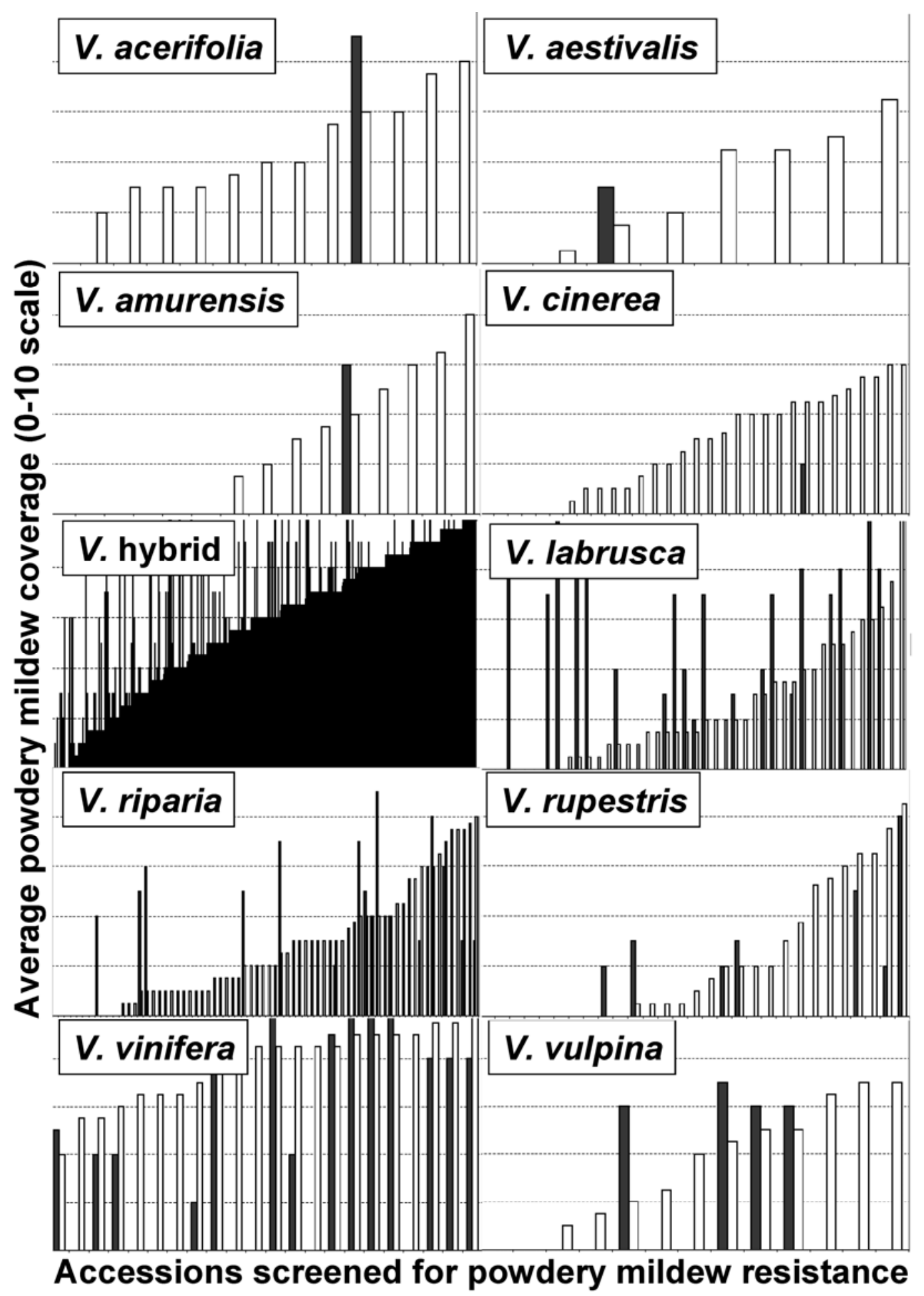

Fig. 1. Powdery mildew coverage of well-represented Vitis spp. by accession following single-isolate inoculation of detached leaves or natural infection in the Geneva, NY repository vineyard. Along the $x$-axis, each accession has a filled bar depicting coverage of detached leaves next to an open bar depicting coverage in the vineyard. Due to the large number of interspecific hybrid accessions presented here $(n=726)$, the open bars are not visibly distinct from filled bars. Accessions are sorted from left to right based on coverage in the vineyard. The same 0 -to- 10 scale is used for all $y$-axes to enable cross-species comparisons. Interspecific hybrids and taxonomic species with eight or more rated accessions are depicted. 
Geneva than in Fredonia (Table 3). The remaining accessions had moderate correlation between coverage on detached leaves and the mean vineyard rating for both Geneva $(r=0.55)$ and Fredonia $(r=0.56)$, and good correlation between Geneva and Fredonia $(r$ $=0.75)$.

Correlation analysis was also conducted, including all data collected in these studies (Table 4). For detached leaf ratings, coverage was highly correlated with sporulation $(r=0.91$; Table 4$)$. Although there were strong correlations within location between years and moderately strong correlations between locations, detached-leaf ratings were not significantly correlated with field ratings (Table 4).
Cross-study comparison of ratings. For 129 interspecific hybrids previously screened for resistance and categorized as resistant, moderate, or susceptible, ratings infrequently corresponded among the previous studies (39\%), between the previous studies and single-isolate inoculations $(46 \%)$, between previous studies and current Geneva vineyard ratings $(41 \%)$, and between previous studies and current Fredonia vineyard ratings (17\%). As examples of the lack of concordance, named cultivars rated in at least two studies are summarized in Tables 5 and 6. Only three cultivars (Cayuga White, Diana, and Mars) with data from four independent studies were resistant in all four studies (Tables 5 and 6). For five accessions of wild species previously rated resistant (20), ratings

Table 3. Foliar powdery mildew coverage on accessions of Vitis spp. showing relative consistency of responses across pathogen sources

\begin{tabular}{|c|c|c|c|c|c|}
\hline \multirow[b]{2}{*}{$\mathbf{P I}^{\mathbf{x}}$} & \multirow[b]{2}{*}{ Accession name ${ }^{y}$} & \multirow[b]{2}{*}{ Vitaceae spp. $^{\mathrm{z}}$} & \multicolumn{3}{|c|}{ Mean coverage $(S D)^{w}$} \\
\hline & & & Geneva & Fredonia & Single isolate \\
\hline 588592 & & Ampelopsis brevipedunculata & $1.0(\mathrm{n} / \mathrm{a})$ & $1.3(1.9)$ & 0 \\
\hline 588442 & GVIT780 & Vitis acerifolia & 0 & $3.9(1.4)$ & 0 \\
\hline 588458 & & $V$. acerifolia & $4.0(\mathrm{n} / \mathrm{a})$ & $5.6(2.1)$ & $0 *$ \\
\hline 588459 & & $V$. acerifolia & $0.0(\mathrm{n} / \mathrm{a})$ & $3.7(2.1)$ & 0 \\
\hline 588459 & & V. acerifolia & $0.0(\mathrm{n} / \mathrm{a})$ & $3.8(2.4)$ & 0 \\
\hline 588459 & & V. acerifolia & $0.0(\mathbf{n} / \mathbf{a})^{*}$ & $5.6(2.6)$ & $0 *$ \\
\hline 237621 & Jaeger & $V$. aestivalis & $6.5(2.1)$ & $7.8(1.7)$ & $\mathbf{0}^{*}$ \\
\hline 483130 & Rem NE 4 & V. aestivalis & $1.5(0.7)$ & $0.9(2.6)$ & $0.8(1.5)$ \\
\hline 483137 & Rem 46-77 & V. aestivalis & $4.5(0.7)$ & $1.8(2.3)$ & 0 \\
\hline 588382 & & V. amurensis & $5.0(7.1)$ & $0.4(0.7)$ & $0 *$ \\
\hline 588629 & & V. amurensis & $6.5(0.7)$ & $3.3(2.9)$ & $0 *$ \\
\hline 588634 & & V. amurensis & $4.0(0.0)$ & $4.3(3.1)$ & $3.0(4.2)$ \\
\hline 588186 & Ill 58 & $V$. cinerea & $6.0(\mathrm{n} / \mathrm{a})$ & $2.6(1.8)$ & $0 *$ \\
\hline 588220 & B 55 & V. cinerea & $4.0(1.4)$ & $2.8(1.1)$ & 0 \\
\hline 588222 & C-66-7 & $V$. cinerea & $3.0(1.4)$ & $2.8(1.3)$ & 0 \\
\hline 588447 & & $V$. cinerea & $4.0(\mathrm{n} / \mathrm{a})$ & $1.7(2.1)$ & 0 \\
\hline 588451 & & V. coignetiae & $3.0(\mathrm{n} / \mathrm{a})$ & $3.6(2.5)$ & 0 \\
\hline 588128 & Vergennes & V. labrusca & 0* & $5.9(1.8)$ & $0 *$ \\
\hline 588145 & GBC 12 & V. labrusca & $2.0(2.8)$ & $5.2(1.8)$ & 0* \\
\hline 588165 & Alba & V. labrusca & 0 & $3.0(1.7)$ & 0 \\
\hline 588173 & GBC 2 & V. labrusca & $1.5(0.7)$ & $4.9(1.5)$ & $3.5(0.7)$ \\
\hline 588277 & Jersey Muscat & V. labrusca & $0.5(0.7)$ & $5.3(1.4)$ & 0* \\
\hline 588307 & Champagne & V. labrusca & $0.5(0.7)^{*}$ & $5.5(2.1)$ & $5.5(4.9)$ \\
\hline 588583 & Grem-4 & V. labrusca & $6.0(1.4)$ & $5.7(2.2)$ & $8.5(2.1)$ \\
\hline 588658 & Lutie & V. labrusca & $5.5(0.7)$ & $6.4(1.6)$ & 0* \\
\hline 594349 & Alexander & V. labrusca & 0 & $4.5(2.0)$ & $3.3(5.8)$ \\
\hline 588201 & GVIT239 & $V$. palmata & $1.5(2.1)$ & $3.3(2.9)$ & $1.5(3.0)$ \\
\hline 588233 & Cache 8 & V. palmata & $0.5(0.7)$ & $0.5(0.8)$ & 0 \\
\hline 313922 & Tarnau & $V$. riparia & $3.0(1.4)$ & $3.2(1.7)$ & 0 \\
\hline 495622 & & V. riparia & $9.0(0.0)$ & $4.9(3.2)$ & $3.0(4.2)$ \\
\hline 588054 & Iowa 7 & V. riparia & $2.5(0.7)$ & $5.1(1.4)$ & $3.5(4.9)$ \\
\hline 588259 & 37 & V. riparia & $1.0(\mathrm{n} / \mathrm{a})$ & $2.5(2.5)$ & 0 \\
\hline 588262 & 89 & V. riparia & $1.5(2.1)$ & $3.3(1.6)$ & 0 \\
\hline 588435 & $2 \mathrm{~F}$ & V. riparia & $5.5(2.1)$ & $4.2(2.2)$ & $0 *$ \\
\hline 588438 & GVIT774 & V. riparia & $1.5(0.7)$ & $1.9(1.2)$ & 0 \\
\hline 588439 & GVIT775 & V. riparia & $5.5(3.5)$ & $4.7(2.5)$ & $0 *$ \\
\hline 588440 & & V. riparia & $1.5(2.1)$ & $1.8(1.8)$ & 0 \\
\hline 588450 & & V. riparia & $5.0(\mathrm{n} / \mathrm{a})$ & $5.7(0.6)$ & 0* \\
\hline 588453 & & $V$. riparia & $0.0(\mathrm{n} / \mathrm{a})$ & $2.6(1.7)$ & 0 \\
\hline 588483 & Rem NE 21 & $V$. riparia & $1.0(1.4)$ & $3.9(2.8)$ & 0 \\
\hline 588565 & Grem & V. riparia & $7.5(2.1)$ & $4.4(3.3)$ & $0 *$ \\
\hline 588587 & & V. riparia & $0.0(\mathbf{n} / \mathbf{a})^{*}$ & $5.1(1.9)$ & $0 *$ \\
\hline 588588 & & V. riparia & $4.0(\mathrm{n} / \mathrm{a})$ & $4.3(2.2)$ & 0 \\
\hline 588590 & & V. riparia & $0.0(\mathrm{n} / \mathrm{a})$ & $3.3(1.6)$ & 0 \\
\hline 588710 & & V. riparia & $3.0(\mathrm{n} / \mathrm{a})$ & $4.2(2.5)$ & 0 \\
\hline 588710 & & V. riparia & $3.0(\mathrm{n} / \mathrm{a})$ & $5.2(1.8)$ & $0 *$ \\
\hline
\end{tabular}

(continued on next page)

${ }^{w}$ Mean and standard deviation (SD) of powdery mildew coverage $(0=0 \%, 1=1-10 \% \ldots 10=100 \%)$, calculated by averaging all rated leaves for that category, based on natural infection of the most heavily infected leaf per vine in Geneva (2007-08) and Fredonia (2006-08) or on single-isolate inoculations with isolate 10-18-1 on detached leaves in 2006. Symbols: 0 indicates accessions with no infection observed across all replicates and n/a indicates the SD for unreplicated observations in the Geneva vineyard. Bold entries with an asterisk are resistant ratings when natural infection in one or both vineyards averaged at least five categories more susceptible; for detached leaves, due to lower average colonization, these are only highlighted when no infection was observed across all replicates.

${ }^{x}$ PI = plant introduction number, a unique identifier for each accession in the Germplasm Resources Information Network (GRIN) database, where PI is linked with additional information related to that accession (http://www.ars-grin.gov/npgs/index.html). Lines with the same PI number (e.g., V. acerifolia 588459) are open-pollinated seedlings from the same mother vine.

y Name listed for each accession, provided in the GRIN database. Accessions of wild species with GVIT numbers listed here were rated by Staudt (20) as resistant.

${ }^{\text {z }}$ Species listed for each accession, provided in the GRIN database. Vitis interspecific hybrids are listed as Vitis hybrid. Unclassified species are listed as Vitis spp. 
confirmed resistance in some screens (Table 3, accessions with GVIT numbers).

\section{Discussion}

Around the world, Vitis germplasm repositories provide an excellent resource for identifying and introgressing new sources of resistance. However, stringent pest management practices are typically followed until fruit harvest, limiting the approaches to obtaining resistance data that fully correspond with field ratings. In addition, field ratings for a given accession often vary from one study to another. Here, three approaches were applied for screening diverse accessions of cold-hardy Vitis spp. for resistance to E. necator-natural, late-season epidemics in the repository, natural infection in an unsprayed and replicated experimental vineyard, and single-isolate inoculations on detached leaves.

Our results support previous findings documenting the presence of race-specific resistance to E. necator (10), and suggest that race specificity could be widespread among resistant Vitis accessions.
Table 4. Correlation analysis of powdery mildew ratings following natural infection or single-isolate inoculations $\mathrm{s}^{\mathrm{z}}$

\begin{tabular}{llc}
\hline Variable 1 & Variable 2 & Correlation $(\boldsymbol{R})$ \\
\hline Leaf sporulation & Leaf coverage & 0.914 \\
2008 Fredonia & 2007 Fredonia & 0.781 \\
2008 Fredonia & 2006 Fredonia & 0.707 \\
2007 Fredonia & 2006 Fredonia & 0.706 \\
2008 Geneva & 2007 Geneva & 0.626 \\
2008 Fredonia & 2007 Geneva & 0.554 \\
2008 Fredonia & 2008 Geneva & 0.520 \\
2007 Fredonia & 2008 Geneva & 0.452 \\
2007 Fredonia & 2007 Geneva & 0.401 \\
2006 Fredonia & 2008 Geneva & 0.347 \\
2006 Fredonia & 2007 Geneva & 0.314 \\
\hline
\end{tabular}

${ }^{\mathrm{z}}$ Based on powdery mildew coverage following natural infections in Geneva (2007 and 2008) or Fredonia (2006, 2007, and 2008) vineyards, or coverage or sporulation for detached leaves inoculated with a single isolate. Statistically nonsignificant comparisons with $P$ values greater than 0.1 are not shown. Comparisons listed here were significant with $P$ values less than 0.006 .

Table 3. (continued from preceding page)

\begin{tabular}{|c|c|c|c|c|c|}
\hline \multirow[b]{2}{*}{$\mathbf{P I}^{\mathbf{x}}$} & \multirow[b]{2}{*}{ Accession name ${ }^{y}$} & \multirow[b]{2}{*}{ Vitaceae spp. $^{\mathrm{z}}$} & \multicolumn{3}{|c|}{ Mean coverage $(S D)^{w}$} \\
\hline & & & Geneva & Fredonia & Single isolate \\
\hline 594344 & Zumbrunnen & $V$. riparia & $4.0(1.4)$ & $5.2(2.3)$ & $2.0(2.8)$ \\
\hline 588146 & R-66-4 & $V$. rupestris & $0 *$ & $5.3(2.9)$ & $0 *$ \\
\hline 588160 & B 38 & $V$. rupestris & $3.8(4.6)$ & $4.4(1.1)$ & 0 \\
\hline 588223 & R-65-43 & $V$. rupestris & $3.0(2.8)$ & $3.6(2.5)$ & 0 \\
\hline 588224 & R-65-44 & $V$. rupestris & $0.5(0.7)$ & $2.5(1.4)$ & $2.5(0.7)$ \\
\hline 588335 & & $V$. rupestris & 0 & $2.1(1.8)$ & 0 \\
\hline 588454 & & $V$. rupestris & $0.0(\mathrm{n} / \mathrm{a})$ & $2.6(1.9)$ & $1.5(2.1)$ \\
\hline 588454 & & $V$. rupestris & $9.0(\mathrm{n} / \mathrm{a})$ & $2.6(1.6) *$ & $0 *$ \\
\hline 588454 & & $V$. rupestris & $10.0(\mathrm{n} / \mathrm{a})$ & $5.8(3.7)$ & $0 *$ \\
\hline 588133 & GBC 5 & V. vulpina & $5.0(2.8)$ & $3.9(3.2)$ & $1.5(3.0)$ \\
\hline 588679 & & V. vulpina & $7.0(0.0)$ & $1.1(2.2)^{*}$ & $0 *$ \\
\hline 588392 & & Vitis $\times$ andersonii & $5.3(2.5)$ & $5.8(1.7)$ & 0* \\
\hline 588149 & GVIT165 & Vitis $\times$ doaniana & 0 & $1.1(2.2)$ & 0 \\
\hline 588257 & & Vitis $\times$ novae-angliae & $4.0(4.2)$ & $4.2(2.7)$ & 0 \\
\hline 588421 & & V. yenshanensis & $10.0(\mathrm{n} / \mathrm{a})$ & $8.9(1.5)$ & $3.0(0.0)$ \\
\hline 588421 & & $V$. yenshanensis & $10.0(\mathrm{n} / \mathrm{a})$ & $9.2(0.7)$ & $1.5(2.1)$ \\
\hline 588421 & & V. yenshanensis & $10.0(\mathrm{n} / \mathrm{a})$ & $9.6(0.7)$ & $5.0(5.8)$ \\
\hline 588421 & & $V$. yenshanensis & $10.0(\mathrm{n} / \mathrm{a})$ & $9.6(1.1)$ & $5.0(5.8)$ \\
\hline 588422 & & $V$. yenshanensis & $5.0(\mathrm{n} / \mathrm{a})$ & $8.2(1.6)$ & $0 *$ \\
\hline 588422 & & $V$. yenshanensis & $10.0(\mathrm{n} / \mathrm{a})$ & $9.3(0.8)$ & $0.5(1.0)$ \\
\hline 588650 & & V. yenshanensis & $10.0(\mathrm{n} / \mathrm{a})$ & $8.4(1.6)$ & $1.0(1.4)$ \\
\hline 157518 & Villard Blanc & Vitis hybrid & $9.5(0.7)$ & $8.6(1.5)$ & $1.0(2.0)$ \\
\hline 175494 & Cascade & Vitis hybrid & $4.5(2.1)$ & $9.0(2.9)$ & $0 *$ \\
\hline 181481 & Vignoles (Ravat 51) & Vitis hybrid & $6.5(2.1)$ & $6.8(1.6)$ & $0.4(0.9)$ \\
\hline 181642 & Bertille Seyve 872 & Vitis hybrid & $8.5(0.7)$ & $9.6(0.5)$ & $1.0(1.4)$ \\
\hline 279899 & Kober $5 \mathrm{BB}$ & Vitis hybrid & $2.0(\mathrm{n} / \mathrm{a})$ & $3.4(1.9)$ & $0.5(0.7)$ \\
\hline 588070 & Catawba & Vitis hybrid & $3.0(2.8)$ & $4.4(2.8)$ & 0 \\
\hline 588077 & Concord & Vitis hybrid & $7.5(0.7)$ & $7.2(2.1)$ & $1.5(2.1)$ \\
\hline 588078 & Delaware & Vitis hybrid & $8.0(1.4)$ & $6.2(1.5)$ & $0.8(1.5)$ \\
\hline 588094 & J.S. 23.416 & Vitis hybrid & $8.0(1.4)$ & $4.7(2.2)$ & $0 *$ \\
\hline 588095 & Himrod & Vitis hybrid & $8.0(0.0)$ & $7.6(1.5)$ & $0 *$ \\
\hline 588107 & Marechal Foch & Vitis hybrid & $6.0(2.8)$ & $8.1(1.3)$ & $0.5(1.0)$ \\
\hline 588111 & Golden Muscat & Vitis hybrid & $6.5(2.1)$ & $6.3(1.5)$ & $0.1(1.2)$ \\
\hline 588113 & Steuben & Vitis hybrid & $7.0(2.8)$ & $7.7(1.2)$ & $0 *$ \\
\hline 588180 & M.G. 101-14 & Vitis hybrid & $7.0(2.8)$ & $5.4(2.4)$ & $8.5(2.1)$ \\
\hline 588196 & Mills & Vitis hybrid & $3.0(0.0)$ & $4.4(1.8)$ & 0 \\
\hline 588234 & Jaeger 70 & Vitis hybrid & $5.0(0.0)$ & $4.3(2.3)$ & $2.0(2.8)$ \\
\hline 588279 & Goethe & Vitis hybrid & $8.5(0.7)$ & $8.9(1.3)$ & $0 *$ \\
\hline 588303 & Clinton & Vitis hybrid & $7.0(\mathrm{n} / \mathrm{a})$ & $6.6(2.6)$ & $0 *$ \\
\hline 588315 & Noah & Vitis hybrid & $3.5(0.7)$ & $4.9(2.8)$ & 0 \\
\hline 588319 & Diana & Vitis hybrid & $2.0(2.8)$ & $2.9(1.4)$ & $0.2(0.4)$ \\
\hline 588327 & Ill 547-1 & Vitis hybrid & $0.0(\mathrm{n} / \mathrm{a})$ & $1.8(2.2)$ & 0 \\
\hline 588397 & & Vitis hybrid & $3.0(\mathbf{n} / \mathbf{a})^{*}$ & $8.2(1.3)$ & $\mathbf{0}^{*}$ \\
\hline 588405 & & Vitis hybrid & $4.0(\mathrm{n} / \mathrm{a})$ & $4.5(3.0)$ & 0 \\
\hline 588419 & & Vitis hybrid & $4.5(0.7)$ & $3.7(1.4)$ & $2.5(3.5)$ \\
\hline 588488 & NY 65.592 .1 & Vitis hybrid & $2.0(2.8)$ & $6.1(2.8)$ & $0.8(1.5)$ \\
\hline 588623 & Taylor & Vitis hybrid & $2.5(2.1)$ & $6.0(1.7)$ & $3.0(0.0)$ \\
\hline 588627 & 7623 & Vitis hybrid & $6.8(3.2)$ & $7.3(1.5)$ & $7.0(4.2)$ \\
\hline 588693 & Ivan & Vitis hybrid & $8.5(0.7)$ & $9.2(1.0)$ & $0 *$ \\
\hline 594334 & Baco noir (Baco 1) & Vitis hybrid & $7.0(1.4)$ & $7.2(1.8)$ & 0* \\
\hline 594346 & Karmrajut & Vitis hybrid & $9.5(0.7)$ & $9.0(2.2)$ & $0 *$ \\
\hline Overall & $\ldots$ & $\ldots$ & $4.2(3.3)$ & $5.0(3.0)$ & $2.7(1.3)$ \\
\hline
\end{tabular}


Of the subset of accessions screened with all three approaches, many $(33 \%)$ were resistant to the single isolate but susceptible in at least one of the vineyards, which could be due to a number of factors, including race specificity, environment, or inoculation protocol. Several accessions (9\%) had differential responses between vineyards. For the remaining accessions, there was a reasonably good correlation between single isolate coverage on older leaves and vineyard ratings ( $r=0.55$ to 0.56 ). Given that one-third of the accessions resistant to a single isolate were susceptible in vineyards, and that accessions susceptible to artificial inoculation were frequently resistant in the vineyard (Fig. 1), there is little to be gained from artificial inoculation with a single isolate in a breeding selection program. However, for isolating, tracking, and pyramiding individual race-specific resistance genes, controlled inoculations with characterized isolates would be highly advantageous.
Nearly all $V$. labrusca accessions were resistant in Geneva, NY but susceptible in Fredonia, NY (Table 3). This is noteworthy because Fredonia (200 km from Geneva) is a center of production for Concord and Niagara, two interspecific hybrids with disease resistance introgressed from $V$. labrusca. This suggests that even within geographic regions, selection could occur for host adaptation, or virulence, on a local scale. This observation fits with findings of Gadoury and Pearson (10), who inoculated the labrusca hybrid Catawba with 46 E. necator isolates; their results revealed a differential ability to infect (qualitative) and colonize (quantitative) Catawba leaves (10), which could explain local selection for virulence.

A number of previous studies have screened diverse germplasm for resistance to grape powdery mildew, including studies focused primarily on interspecific hybrids, wild species, or both. In most of

Table 5. Powdery mildew resistance ratings for accessions of Vitis interspecific hybrids rated in Eibach (7) and in the current study

\begin{tabular}{|c|c|c|c|c|}
\hline \multirow[b]{2}{*}{ Plant ID ${ }^{y}$} & \multirow[b]{2}{*}{$\mathbf{P I} \mathbf{y}^{\mathbf{n}}$} & \multirow[b]{2}{*}{ Eibach $^{\text {z }}$} & \multicolumn{2}{|c|}{ Cadle-Davidson $^{x}$} \\
\hline & & & Geneva/Fredonia & Single isolate \\
\hline Agawam & 588211 & $\mathrm{~S}$ & $\mathrm{~S}$ & $S$ \\
\hline Alden & 588102 & $\mathrm{R}$ & M & $\ldots$ \\
\hline Alwood & 588081 & $\mathrm{R}$ & M & $\mathrm{R}$ \\
\hline Atoka & 588551 & M & $\mathrm{S}$ & $\ldots$ \\
\hline Baco noir (Baco 1) & 594334 & M & $\mathrm{S} / \mathrm{S}$ & $\mathrm{R}$ \\
\hline Bailey Alicante & 588361 & $\mathrm{~S}$ & $\mathrm{M}$ & M \\
\hline Bath & 597101 & $\mathrm{R}$ & M & $\mathrm{S}$ \\
\hline Bertille Seyve 3408 & 597146 & $\mathrm{R}$ & $\mathrm{S}$ & $\ldots$ \\
\hline Bertille Seyve 4825 & 181646 & M & M & $\mathrm{R}$ \\
\hline Beta & 588148 & $\mathrm{R}$ & $\mathrm{S}$ & $\mathrm{R}$ \\
\hline Bianca & 597287 & $\mathrm{R}$ & $\mathrm{S}$ & $\mathrm{S}$ \\
\hline Black Eagle & 597206 & M & S & $\mathrm{S}$ \\
\hline Bluestar & 597211 & $\mathrm{R}$ & M & $\mathrm{R}$ \\
\hline Brighton & 597201 & M & $\mathrm{R}$ & $\ldots$ \\
\hline Bronx Seedless & 588126 & $\mathrm{~S}$ & $\mathrm{~S}$ & $\ldots$ \\
\hline Burdin 4672 & 597160 & M & $\mathrm{S}$ & $\mathrm{R}$ \\
\hline Canada Muscat & 588080 & $\mathrm{R}$ & M & $\ldots$ \\
\hline Canadice (NY 45625) & 588096 & M & $\mathrm{R}$ & $\mathrm{R}$ \\
\hline Cascade (Seibel 13.053) & 175494 & $\mathrm{~S}$ & $\mathrm{R} / \mathrm{S}$ & $\mathrm{R}$ \\
\hline Century 1 & 597264 & $\mathrm{~S}$ & $\mathrm{~S}$ & $\mathrm{~S}$ \\
\hline Chambourcin (J.S. 26.205) & 588075 & M & $\mathrm{S}$ & $\mathrm{R}$ \\
\hline Chancellor (Seibel 7053) & 588072 & $\mathrm{R}$ & $\mathrm{S}$ & $\mathrm{R}$ \\
\hline Chelois (Seibel 10.878) & 588071 & $\mathrm{R}$ & $\mathrm{R}$ & $\ldots$ \\
\hline Colobel (Seibel 8357) & 588062 & $\mathrm{R}$ & S & $\mathrm{R}$ \\
\hline Couderc Noir (Couderc 7120) & 597143 & $\mathrm{R}$ & M & $\ldots$ \\
\hline Croton & 597207 & $\mathrm{R}$ & $\mathrm{S}$ & M \\
\hline De Chaunac (Seibel 9549) & 371984 & M & $\mathrm{S}$ & $\mathrm{R}$ \\
\hline Diana & 588319 & $\mathrm{R}$ & $\mathrm{R} / \mathrm{R}$ & $\mathrm{R}$ \\
\hline Dunkirk & 597171 & M & $\mathrm{M}$ & M \\
\hline Florental (Burdin 7705) & 256487 & $\mathrm{R}$ & M & $\mathrm{R}$ \\
\hline Glenora (NY 35814) & 597100 & M & $\mathrm{R}$ & $\ldots$ \\
\hline Goff & 597107 & $\mathrm{~S}$ & M & M \\
\hline Golden Muscat & 588111 & M & $\mathrm{M} / \mathrm{M}$ & M \\
\hline Hanover & 597113 & $\mathrm{R}$ & M & $\ldots$ \\
\hline Hector & 597132 & $\mathrm{R}$ & $\mathrm{R}$ & $\ldots$ \\
\hline Herbert & 588150 & $\mathrm{~S}$ & $\mathrm{~S}$ & $\mathrm{R}$ \\
\hline Himrod & 588095 & $\mathrm{R}$ & $\mathrm{S} / \mathrm{S}$ & $\ldots$ \\
\hline Interlaken & 597241 & $\mathrm{~S}$ & $\mathrm{~S}$ & $\ldots$ \\
\hline Iona & 588193 & $\mathrm{R}$ & $\mathrm{R}$ & $\mathrm{R}$ \\
\hline Joannes Seyve 23.416 & 588094 & $\mathrm{R}$ & $\mathrm{S} / \mathrm{M}$ & $\mathrm{R}$ \\
\hline Karmrajut & 594346 & $\mathrm{~S}$ & $\mathrm{~S}$ & $\ldots$ \\
\hline Lady Patricia & 588089 & $\mathrm{R}$ & $\mathrm{S}$ & $\mathrm{M}$ \\
\hline Lakemont & 588383 & M & $\mathrm{S}$ & $\ldots$ \\
\hline Landot 1678 & 597142 & $\mathrm{R}$ & $\mathrm{S}$ & $\mathrm{R}$ \\
\hline Leon Millot (Kuhlmann 194-2) & 588112 & $\mathrm{~S}$ & $\mathrm{M}$ & $\mathrm{R}$ \\
\hline
\end{tabular}

(continued on next page)

${ }^{x}$ Data from the current study. All interspecific hybrids shown here were rated in Geneva and, for the few that were rated in Fredonia, ratings are listed as "Geneva/Fredonia". For natural infection, ratings were categorized: below $3.5=$ resistant $(\mathrm{R}) ; 3.5$ to $5.4=$ moderate $(\mathrm{M}) ; 5.5$ or greater $=$ susceptible $(\mathrm{S})$; and no data $=\ldots$ Single-isolate ratings were categorized based on the mean of all rated leaves as follows: below $2=\mathrm{R} ; 2$ to $5.4=\mathrm{M} ; 5.5$ or greater $=\mathrm{S} ;$ and no data $=\ldots$.

y PI = Plant Introduction number, a unique identifier for each accession in the Germplasm Resources Information Network database, where PI is linked with additional information related to that accession, including a Plant ID (http://www.ars-grin.gov/npgs/index.html). A PI number has not yet been assigned to Roucaneuf (GVIT 1676).

${ }^{\mathrm{z}}$ Eibach (7) rated coverage of necrosis and mycelia from 1991 to 1993 on naturally infected vines in Geilweilerhof, Germany and reported the maximum degree of infection on a 1-to-9 scale. Here, ratings were categorized: 1 to $3=\mathrm{R}, 4$ to $5=\mathrm{M}, 6$ to $8=\mathrm{S}$, and no data $=\ldots$. 
the studies involving wild species, a single accession was used to represent each wild species, and the identity of that accession was not provided, eliminating the possibility of cross-study comparisons. However, Staudt (20) screened leaf discs of multiple accessions per species, identified intraspecific variation, and provided identification for some of the accessions tested, allowing rating comparisons with the current data set. Although ratings of individual accessions corresponded well between that study and the current study (Table 3, accessions with GVIT numbers), species with only susceptible accessions in Staudt (20) frequently had some resistant accessions in the current study. For nearly all of the 135 cultivars screened in this and previous studies, ratings infrequently corresponded among previous studies (39\%) and between the current and previous studies (17 to 46\%). Among cultivars rated in the United States and elsewhere, Athens, Campbell Early, Cayuga
White, Diana, Iona, and Mars were the only cultivars consistently rated resistant in at least three studies, even though most of the cultivars listed (75\%) were resistant in at least one study.

In the current study, extensive effort was spent precisely phenotyping sporulation under the microscope for thousands of leaves. However, coverage and sporulation were highly correlated $(r=$ 0.91 to 0.92 ), suggesting that the effort required for rating sporulation provided little additional information.

Here, we showed that, whereas some Vitis spp. are, on average, more resistant than others, nearly all Vitis spp. have both resistant and susceptible accessions, and we provided additional evidence suggesting that pathogen genotype may affect resistance phenotype. In addition, for grape breeding programs interested in broadspectrum resistance, the lack of correspondence between powdery mildew resistance screens highlights the importance of confirming

Table 5. (continued from preceding page)

\begin{tabular}{|c|c|c|c|c|}
\hline \multirow[b]{2}{*}{ Plant ID } & \multirow[b]{2}{*}{$\mathbf{P I}^{\mathbf{y}}$} & \multirow[b]{2}{*}{ Eibach $^{z}$} & \multicolumn{2}{|c|}{ Cadle-Davidson $^{x}$} \\
\hline & & & Geneva/Fredonia & Single isolate \\
\hline Marechal Joffre (Kuhlmann 187-1) & 588254 & $\mathrm{R}$ & M & M \\
\hline Missouri Riesling & 588285 & $\mathrm{R}$ & $\mathrm{S}$ & M \\
\hline Naples & 597205 & $\mathrm{R}$ & $\mathrm{S}$ & $\mathrm{R}$ \\
\hline Noah & 588315 & M & $\mathrm{M} / \mathrm{M}$ & $\mathrm{R}$ \\
\hline Norwood & 597263 & $\mathrm{R}$ & $\mathrm{S}$ & $\ldots$ \\
\hline Oberlin 604 & 279509 & M & $\mathrm{R}$ & $\mathrm{R}$ \\
\hline Othello & 588310 & $\mathrm{R}$ & $\mathrm{S}$ & M \\
\hline Plantet (Seibel 5455) & 588179 & $\mathrm{R}$ & $\mathrm{S}$ & $\mathrm{R}$ \\
\hline Price & 588105 & $\mathrm{R}$ & M & $\ldots$ \\
\hline Ravat Blanc (Ravat 6) & 588522 & M & $\mathrm{S}$ & $\mathrm{S}$ \\
\hline Reliance & 597233 & $\mathrm{R}$ & $\mathrm{S}$ & $\mathrm{R}$ \\
\hline Romulus & 597095 & M & $\mathrm{S}$ & $\mathrm{S}$ \\
\hline Roucaneuf & $\mathrm{n} / \mathrm{a}$ & $\mathrm{R}$ & $\mathrm{S}$ & $\ldots$ \\
\hline Schuyler & 588099 & $\mathrm{R}$ & $\mathrm{S}$ & $\mathrm{R}$ \\
\hline Seibel 11.342 & 163512 & $\mathrm{R}$ & $\mathrm{S}$ & $\mathrm{M}$ \\
\hline Seibel 15.051 & 187218 & M & M & $\ldots$ \\
\hline Seibel 880 & 588314 & $\mathrm{R}$ & $\mathrm{S}$ & $\mathrm{R}$ \\
\hline Seneca & 588076 & $\mathrm{~S}$ & M & $\ldots$ \\
\hline Seyval (Seyve-Villard 5.276) & 588309 & $\mathrm{R}$ & M & $\mathrm{R}$ \\
\hline Seyve-Villard 10.271 & 181605 & $\mathrm{R}$ & $\mathrm{R}$ & $\ldots$ \\
\hline Seyve-Villard 12.303 & 597138 & $\mathrm{R}$ & $\mathrm{S}$ & $\ldots$ \\
\hline Seyve-Villard 12.347 & 597272 & $\mathrm{R}$ & $\mathrm{S}$ & $\mathrm{R}$ \\
\hline Seyve-Villard 15.151 & 181624 & $\mathrm{R}$ & M & $\ldots$ \\
\hline Seyve-Villard 23.512 & 181639 & $\mathrm{~S}$ & $\mathrm{~S}$ & $\mathrm{R}$ \\
\hline Seyve-Villard 26.166 & 597290 & M & M & $\ldots$ \\
\hline Seyve-Villard 28-86 & 597288 & $\mathrm{R}$ & $\mathrm{S}$ & M \\
\hline Seyve-Villard 34.211 & 588702 & M & $\mathrm{S}$ & $\ldots$ \\
\hline Seyve-Villard 5.247 & 181603 & $\mathrm{R}$ & M & $\mathrm{R}$ \\
\hline Sheridan & 588171 & $\mathrm{~S}$ & M & $\mathrm{R}$ \\
\hline Sovereign Charter & 588469 & $\mathrm{R}$ & $\ldots$ & $\mathrm{S}$ \\
\hline Sovereign Coronation & 588086 & M & $\mathrm{S}$ & M \\
\hline Sovereign Noir & 588471 & $\mathrm{R}$ & M & $\mathrm{R}$ \\
\hline Sovereign Rose & 588470 & $\mathrm{R}$ & $\mathrm{R}$ & $\mathrm{S}$ \\
\hline Sovereign Tiara & 588468 & $\mathrm{~S}$ & $\mathrm{~S}$ & M \\
\hline Stepnyak & 594345 & $\mathrm{R}$ & $\mathrm{R}$ & $\mathrm{S}$ \\
\hline Stout Seedless & 597204 & $\mathrm{~S}$ & $\mathrm{~S}$ & M \\
\hline Suffolk Red & 597242 & $\mathrm{R}$ & $\mathrm{S}$ & M \\
\hline Taylor & 588623 & M & $\mathrm{R} / \mathrm{M}$ & M \\
\hline Telegraph & 597099 & M & $\mathrm{R}$ & M \\
\hline Totmur (Baco 2-16) & 188597 & $\mathrm{R}$ & $\mathrm{S}$ & M \\
\hline Valerien (Seyve-Villard 23.410) & 181632 & M & $\mathrm{S}$ & $\mathrm{S}$ \\
\hline Valiant & 588266 & $\mathrm{~S}$ & $\mathrm{R}$ & $\mathrm{R}$ \\
\hline Vanessa Seedless & 588288 & M & $\mathrm{S}$ & M \\
\hline Veeblanc & 597181 & $\mathrm{~S}$ & $\mathrm{~S}$ & $\mathrm{R}$ \\
\hline Ventura & 588066 & $\mathrm{R}$ & $\mathrm{R}$ & $\mathrm{S}$ \\
\hline Venus & 597243 & M & M & M \\
\hline Vergennes (V. labrusca) & 588128 & $\mathrm{R}$ & $\mathrm{R} / \mathrm{M}$ & $\mathrm{R}$ \\
\hline Vignoles (Ravat 51) & 181481 & $\mathrm{R}$ & $\mathrm{S} / \mathrm{S}$ & $\mathrm{R}$ \\
\hline Vincent & 588108 & $\mathrm{~S}$ & $\mathrm{~S}$ & $\ldots$ \\
\hline Vinered & 588093 & $\mathrm{~S}$ & $\mathrm{R}$ & $\mathrm{S}$ \\
\hline Vivant & 597231 & M & $\mathrm{S}$ & $\ldots$ \\
\hline Watkins (NY7588) & 588695 & $\mathrm{R}$ & $\mathrm{S}$ & $\mathrm{R}$ \\
\hline Wayne & 597122 & M & $\mathrm{R}$ & $\mathrm{S}$ \\
\hline Westfield & 588131 & M & M & M \\
\hline Yates & 588114 & M & $\mathrm{S}$ & $\mathrm{S}$ \\
\hline
\end{tabular}


Table 6. Powdery mildew resistance ratings for named cultivars of Vitis spp. screened in at least two studies ${ }^{t}$

\begin{tabular}{|c|c|c|c|c|c|c|c|c|c|}
\hline \multirow[b]{2}{*}{ Plant ID w } & \multirow[b]{2}{*}{$\mathbf{P I}^{\mathbf{w}}$} & \multicolumn{3}{|c|}{ Cadle-Davidson $^{\mathrm{u}}$} & \multicolumn{2}{|c|}{ Eibach $^{v}$} & \multirow[b]{2}{*}{$\operatorname{Roy}^{x}$} & \multirow[b]{2}{*}{ Suit $^{y}$} & \multirow[b]{2}{*}{ Other ${ }^{\mathrm{z}}$} \\
\hline & & Geneva & Fredonia & Single & 1994 & 1989 & & & \\
\hline Athens & 588158 & $\mathrm{R}$ & $\ldots$ & $\mathrm{R}$ & $\ldots$ & $\ldots$ & $\ldots$ & $\ldots$ & $\mathrm{R}$ \\
\hline AxRno. 1 & 588092 & $\mathrm{R}$ & $\ldots$ & $\mathrm{R}$ & $\ldots$ & $\ldots$ & M & $\ldots$ & $\ldots$ \\
\hline Bacchus & 588297 & $\mathrm{M}$ & $\ldots$ & $\mathrm{R}$ & $\ldots$ & $\ldots$ & $\mathrm{S}$ & $\ldots$ & $\ldots$ \\
\hline Baco blanc & 312797 & $\mathrm{~S}$ & $\ldots$ & $\ldots$ & M & $\mathrm{R}$ & $\ldots$ & $\ldots$ & $\ldots$ \\
\hline Baroque & 588326 & M & $\ldots$ & M & $\ldots$ & $\ldots$ & $\mathrm{R}$ & $\ldots$ & $\ldots$ \\
\hline Campbell Early & 588122 & $\mathrm{R}$ & $\ldots$ & $\ldots$ & $\mathrm{R}$ & $\ldots$ & $\ldots$ & $\ldots$ & $\mathrm{R}$ \\
\hline Castel 19.637 & 188582 & $\mathrm{~S}$ & $\ldots$ & $\mathrm{R}$ & $\ldots$ & $\mathrm{R}$ & $\ldots$ & $\ldots$ & $\ldots$ \\
\hline Catawba & 588070 & M & M & $\mathrm{R}$ & $\mathrm{R}$ & $\ldots$ & M & M & $\mathrm{R}$ \\
\hline Cayuga White & 588079 & $\mathrm{R}$ & $\ldots$ & $\mathrm{R}$ & $\mathrm{R}$ & $\ldots$ & $\mathrm{R}$ & $\ldots$ & $\ldots$ \\
\hline Clinton & 588303 & $\ldots$ & $\mathrm{S}$ & $\mathrm{R}$ & $\ldots$ & $\ldots$ & $\mathrm{R}$ & $\mathrm{R}$ & $\ldots$ \\
\hline Concord & 588077 & $\mathrm{~S}$ & $\mathrm{~S}$ & $\mathrm{R}$ & M & $\ldots$ & M & $\mathrm{S}$ & $\mathrm{R}$ \\
\hline Delaware & 588078 & $\mathrm{~S}$ & $\mathrm{~S}$ & M & M & $\ldots$ & M & $\mathrm{R}$ & $\ldots$ \\
\hline Dutchess & 588109 & M & $\ldots$ & $\mathrm{S}$ & $\mathrm{R}$ & $\ldots$ & M & $\mathrm{R}$ & $\ldots$ \\
\hline Elvira & 588298 & $\mathrm{R}$ & $\ldots$ & $\ldots$ & $\mathrm{R}$ & $\ldots$ & M & $\mathrm{R}$ & $\ldots$ \\
\hline Fredonia & 597098 & M & $\ldots$ & $\mathrm{S}$ & $\ldots$ & $\ldots$ & M & M & $\ldots$ \\
\hline Isabella & 588207 & $\mathrm{R}$ & $\mathrm{M}$ & $\ldots$ & $\mathrm{S}$ & $\ldots$ & $\ldots$ & $\ldots$ & $\mathrm{R}$ \\
\hline Ives & 588110 & $\mathrm{R}$ & $\ldots$ & M & $\ldots$ & $\ldots$ & $\mathrm{R}$ & $\mathrm{R}$ & $\ldots$ \\
\hline Marechal Foch & 588107 & M & $\mathrm{S}$ & $\mathrm{R}$ & $\mathrm{R}$ & $\mathrm{R}$ & $\ldots$ & $\ldots$ & Var \\
\hline Mars & 597234 & $\mathrm{R}$ & $\ldots$ & $\mathrm{R}$ & $\mathrm{R}$ & $\ldots$ & $\mathrm{R}$ & $\ldots$ & $\ldots$ \\
\hline Niabell & 597275 & $\mathrm{~S}$ & $\ldots$ & $\ldots$ & $\ldots$ & $\ldots$ & $\mathrm{R}$ & $\ldots$ & $\ldots$ \\
\hline Niagara & 588106 & $\mathrm{~S}$ & $\mathrm{R}$ & $\mathrm{S}$ & M & $\ldots$ & M & M & $\mathrm{R}$ \\
\hline Riesling (white) & 588673 & $\mathrm{~S}$ & $\ldots$ & $\ldots$ & $\ldots$ & $\mathrm{S}$ & M & $\ldots$ & $\mathrm{S}$ \\
\hline Rkaziteli & 588177 & M & $\ldots$ & $\ldots$ & $\ldots$ & $\ldots$ & $\mathrm{R}$ & $\ldots$ & $\mathrm{R}$ \\
\hline Rosette & 588290 & $\mathrm{~S}$ & $\ldots$ & $\ldots$ & M & $\ldots$ & $\mathrm{S}$ & $\ldots$ & $\ldots$ \\
\hline Steuben & 588113 & M & $\ldots$ & $\ldots$ & M & $\ldots$ & $\mathrm{R}$ & $\ldots$ & $\ldots$ \\
\hline Vidal Blanc (Vidal 256) & 200684 & $\mathrm{R}$ & $\ldots$ & M & $\mathrm{R}$ & $\mathrm{R}$ & $\ldots$ & $\ldots$ & $\ldots$ \\
\hline Villard blanc & 157518 & $\mathrm{~S}$ & $\mathrm{~S}$ & $\ldots$ & $\mathrm{R}$ & $\ldots$ & $\ldots$ & $\ldots$ & M \\
\hline Villard noir & 588291 & $\mathrm{~S}$ & $\ldots$ & M & $\mathrm{R}$ & $\ldots$ & $\ldots$ & $\ldots$ & M \\
\hline
\end{tabular}

${ }^{\mathrm{t}}$ For all studies, ... denotes no data.

" Data from the current study. For natural infection, ratings were categorized: below $3.5=$ resistant $(\mathrm{R}), 3.5$ to $5.4=$ moderate $(\mathrm{M})$, and 5.5 or greater $=$ susceptible (S). Single-isolate (Single) ratings were categorized based on the mean of all rated leaves as follows: below $2=\mathrm{R}, 2$ to $5.4=\mathrm{M}$, and 5.5 or greater $=\mathrm{S}$.

$\checkmark$ Eibach (7) rated coverage of necrosis and mycelia from 1991 to 1993 on naturally infected vines in Geilweilerhof, Germany and reported the maximum degree of infection on a 1-to- 9 scale. Here, ratings were categorized: 1 to $3=\mathrm{R}, 4$ to $5=\mathrm{M}$, and 6 to $9=\mathrm{S}$. Eibach et al. (8) used an inverse scale to rate inoculated leaves, here categorized as 1 to $3=\mathrm{S}, 4$ to $5=\mathrm{M}$, and 6 to $9=\mathrm{R}$.

${ }^{\mathrm{w}} \mathrm{PI}=$ Plant Introduction number, a unique identifier for each accession in the Germplasm Resources Information Network database, where PI is linked with additional information related to that accession, including a Plant ID (http://www.ars-grin.gov/npgs/index.html).

${ }^{x}$ Roy and Ramming (19) reviewed the literature and categorized resistance into five classes: significantly resistant (R), moderately resistant and two intermediate classes $(\mathrm{M})$, and significantly susceptible $(\mathrm{S})$.

y Suit (22) rated natural infections in grower vineyards across New York State from 1940 to 1944, and provided ratings on relative susceptibility. Ratings were categorized here as follows: $0=\mathrm{R},+=\mathrm{M}$, and $+++=\mathrm{S}$.

${ }^{z}$ Patil et al. (15) reported summaries of natural infections occurring in a vineyard in Hol (Pune), Maharashtra, India from 1982 to 1988 . Only R accessions were reported, including Athens, Catawba, Concord, Isabella, and Rkaziteli. Doster and Schatnorst (6) inoculated cuttings in a growth chamber and monitored latent period at $20^{\circ} \mathrm{C}$. Cultivars that did not allow sporulation within the nine day duration of the experiment are listed here as $\mathrm{R}$, including Concord and Niagara. Stein et al. (21) evaluated resistance to powdery mildew on artificially inoculated leaves and leaf discs from the vineyard or greenhouse and ranked cultivars from most susceptible to most resistant. Riesling was consistently among the six most susceptible (S), and Marechal Foch was variable (Var), being among the six most resistant or the six intermediate, depending on experiment. Peros et al. (18) inoculated detached leaves with conidial droplets and measured incidence of infection and colony diameter by leaf age. Villard blanc and Villard noir were intermediate (M) in susceptibility relative to S (Cabernet Sauvignon) and R (Jacquez) checks. Wan et al. (24) evaluated resistance to natural infections in a vineyard in Yangling, Shaanxi, China, from 2001 to 2003, identifying individuals as highly resistant, resistant (R; Campbell Early), susceptible, and highly susceptible.

resistance across multiple geographic regions with the use of uniform testing procedures. In most cases, when considering cultivar development and release, the possible threat of virulent isolates justifies the pyramiding of multiple resistance genes and the use of complementary control tactics to protect resistance gene efficacy.

\section{Acknowledgments}

We thank J. Daeffler, M. Hannan, C. Geartz, and J. D'Amato for technical support in collecting, sterilizing, plating, tracking, inoculating, and rating the detached leaves, a process that involved over 45,000 sample touches for this project; the ARS-PGRU and Cornell Fredonia Vineyard Laboratory for vineyard maintenance and coordination of sample and data collection; and M. CadleDavidson and P. Cousins for critical review of the manuscript. This research was supported by USDA-ARS CRIS Project 1910-21220-002-00D at the Grape Genetics Research Unit and by two grants from the USDA-ARS Germplasm Evaluation Program.

\section{Literature Cited}

1. Akkurt, M., Welter, L., Maul, E., Topfer, R., and Zyprian, E. 2007. Development of SCAR markers linked to powdery mildew (Uncinula necator) resistance in grapevine (Vitis vinifera L. and Vitis sp.). Mol. Breed. 19:103-111.
2. Barker, C. L., Donald, T., Pauquet, J., Ratnaparkhe, M. B., Bouquet, A. Adam-Blondon, A. F., Thomas, M. R., and Dry, I. 2005. Genetic and physical mapping of the grapevine powdery mildew resistance gene, Run1, using a bacterial artificial chromosome library. Theor. Appl. Genet. 111:370-377.

3. Coleman, C., Copetti, D., Cipriani, G., Hoffmann, S., Kozma, P., Kovacs, L., Morgante, M., Testolin, R., and Di Gaspero, G. 2009. The powdery mildew resistance gene REN1 co-segregates with an NBS-LRR gene cluster in two Central Asian grapevines. BMC Genet. 10:89.

4. Dalbo, M. A., Ye, G. N., Weeden, N. F., Wilcox, W. F., and Reisch, B. I. 2001. Marker-assisted selection for powdery mildew resistance in grapes. J. Am. Soc. Hortic. Sci. 126:83-89.

5. Di Gaspero, G., Cipriani, G., Adam-Blondon, A. F., and Testolin, R. 2007. Linkage maps of grapevine displaying the chromosomal locations of 420 microsatellite markers and 82 markers for R-gene candidates. Theor. Appl. Genet. 114:1249-1263.

6. Doster, M. A., and Schnathorst, W. C. 1985. Comparative susceptibility of various grapevine cultivars to the powdery mildew fungus Uncinula necator. Am. J. Enol. Vitic. 36:101-104.

7. Eibach, R. 1994. Investigations about the genetic resources of grapes with regard to resistance characteristics to powdery mildew (Oidium tuckeri). Vitis $33: 143-150$.

8. Eibach, R., Diehl, H., and Alleweldt, G. 1989. Investigations on the herita- 
bility of resistance to Oidium tuckeri, Plasmopara viticola and Botrytis cinerea in grapes. Vitis 28:209-228.

9. Eibach, R., Zyprian, E., Welter, L., and Topfer, R. 2007. The use of molecular markers for pyramiding resistance genes in grapevine breeding. Vitis 46:120-124.

10. Gadoury, D. M., and Pearson, R. C. 1991. Heterothallism and pathogenic specialization in Uncinula necator. Phytopathology 81:1287-1293.

11. Hoffmann, S., Di Gaspero, G., Kovacs, L., Howard, S., Kiss, E., Galbacs, Z., Testolin, R., and Kozma, P. 2008. Resistance to Erysiphe necator in the grapevine 'Kishmish vatkana' is controlled by a single locus through restriction of hyphal growth. Theor. Appl. Genet. 116:427-438.

12. Large, E. C. 1940. The Advance of the Fungi. Henry Holt and Co., New York.

13. Mahanil, S., Reisch, B. I., Owens, C. L., Thipyapong, P., and Laosuwan, P. 2007. Resistance gene analogs from Vitis cinerea, Vitis rupestris, and Vitis hybrid Horizon. Am. J. Enol. Vitic. 58:484-493.

14. Molnar, S., Galbacs, Z., Halasz, G., Hoffmann, S., Kiss, E., Kozma, P., Veres, A., Galli, Z., Szoke, A., and Heszky, L. 2007. Marker assisted selection (MAS) for powdery mildew resistance in a grapevine hybrid family. Vitis $46: 212-213$.

15. Patil, S. G., Honrao, B. K., Rao, V. G., and Patil, V. P. 1990. Screening of grape (Vitis species) germplasm for resistance to 3 major fungal diseases. Indian J. Agric. Sci. 60:836-838.

16. Pauquet, J., Bouquet, A., This, P., and Adam-Blondon, A. F. 2001. Establishment of a local map of AFLP markers around the powdery mildew resistance gene Runl in grapevine and assessment of their usefulness for marker assisted selection. Theor. Appl. Genet. 103:1201-1210.

17. Pavlousek, P. 2007. Evaluation of resistance to powdery mildew in grapevine genetic resources. J. Cent. Eur. Agric. 8:105-114.
18. Peros, J. P., Nguyen, T. H., Troulet, C., Michel-Romiti, C., and Notteghem, J. L. 2006. Assessment of powdery mildew resistance of grape and Erysiphe necator pathogenicity using a laboratory assay. Vitis 45:29-36.

19. Roy, R. R., and Ramming, D. W. 1990. Varietal resistance of grape to the powdery mildew fungus, Uncinula necator. Fruit Var. J. 44:149-155.

20. Staudt, G. 1997. Evaluation of resistance to grapevine powdery mildew (Uncinula necator Schw. Burr., anamorph Oidium tuckeri Berk.) in accessions of Vitis species. Vitis 36:151-154.

21. Stein, U., Heintz, C., and Blaich, R. 1985. The in vitro examination of grapevines regarding resistance to powdery and downy mildew. Z Pflanzenkrankh. Pflanzenschutz 92:355-369.

22. Suit, R. F. 1945. Field results on the control of certain grape diseases in New York. N. Y. Agric. Exp. Stn. Bull. 712.

23. USDA-ARS National Plant Germplasm System. 2010. Germplasm Resources Information Network (GRIN), Beltsville, MD. Available from http://www.arsgrin.gov/npgs/index.html.

24. Wan, Y. Z., Schwaninger, H., He, P. C., and Wang, Y. J. 2007. Comparison of resistance to powdery mildew and downy mildew in Chinese wild grapes. Vitis 46:132-136.

25. Wang, Y., Liu, Y., He, P., Chen, J., Lamikanra, O., and Lu, J. 1995. Evaluation of foliar resistance to Uncinula necator in Chinese wild Vitis species. Vitis 34:159-164

26. Welter, L. J., Gokturk-Baydar, N., Akkurt, M., Maul, E., Eibach, R., Topfer, R., and Zyprian, E. M. 2007. Genetic mapping and localization of quantitative trait loci affecting fungal disease resistance and leaf morphology in grapevine (Vitis vinifera L). Mol. Breed. 20:359-374.

27. Wilcox, W. F., Agnello, A. M., Pearson, R. C., Dennehy, T. J., Pool, R. M., Reisch, B. I., Zabadal, T. J., and Himelrick, D. G. 1987. 1987 Grape pest control guide. N.Y. Coop. Ext. Ser. 